\title{
Spiders (Araneae) from the Lena and Yana Rivers, Yakutia (Sakha Republic)
}

\author{
Seppo Koponen, Yuri M. Marusik \& Nadezhda K. Potapova
}

Koponen, S., Marusik, Yu.M. \& Potapova, N.K. 2004: Spiders (Araneae) from the Lena and Yana Rivers, Yakutia (Sakha Republic). — Entomol. Fennica 15: $113-118$.

Seventy-seven species of spiders are reported from the Lena and Yana River basins, and zoogeographical notes are given for 23 of these. Four species, Clubiona stagnatilis Kulczynski, 1897, Zelotes fratris Chamberlin, 1920, Pardosa jeniseica Eskov \& Marusik, 1995 and Wiehlenarius boreus Eskov, 1990, are reported for the first time from Yakutia. The northernmost known localities were found for Zelotes fratris, Pardosa lyrata (Odenwall, 1901), Evarcha proszynskii Marusik \& Logunov, 1998 and Pellenes limbatus Kulczynski, 1895, and the northernmost records in Asia for Clubiona stagnatilis and Theridion impressum L. Koch, 1881.

S. Koponen, Zoological Museum, Centre for Biodiversity, University of Turku, FI-20014Turku,Finland; E-mail: sepkopo@utu.fi

Y. M. Marusik, Institute for Biological Problems of the North, Russian Academy of Sciences, Portovaya Str. 18, Magadan 685000, Russia

N. K. Potapova, Institute for Biological Problems of Cryolithozone, Siberian Division of the Russian Academy of Sciences, Prospect Lenina 41, Yakutsk 677891, Russia

Received 27 January 2004, accepted 26 April 2004

\section{Introduction}

Yakutia (or the Sakha Republic) is the largest administrative unit of Russia, with an area of about 3.1 million sq. $\mathrm{km}$. The first paper on Yakutian spiders was written by Kulczynski (1908) although some data were included already in Grube (1861-62). A remarkable addition to the spider fauna of Yakutia was given by Koponen \& Marusik (1992) based on the material collected by the author SK in late 1970s. The checklist of Yakutian spiders is already more than ten years old (Marusik et al. 1993). At present, the spider fauna includes ca. 435 species. The real species number is much higher, because large areas are still almost unstudied; at least 600-700 species of spiders can be expected to be found (Marusik \& Koponen 2002).

A century ago, in 1901, two young Finnish biologists, A. K. Cajander and R. B. Poppius, made a field expedition along the Lena River. This long trip resulted in well-known studies on alluvial and forest vegetation by Cajander (Hämet-Ahti 1970). Poppius published four papers on Coleoptera of the Lena River valley, and described over 70 new species (Poppius 19051909). Poppius also collected some spiders, which were identified 90 years later, and his records on 36 species were included in the Yakutian check-list (Marusik et al. 1993). To commemorate this scientifically extraordinary expedition, Yakutian and Finnish researchers in biology and 


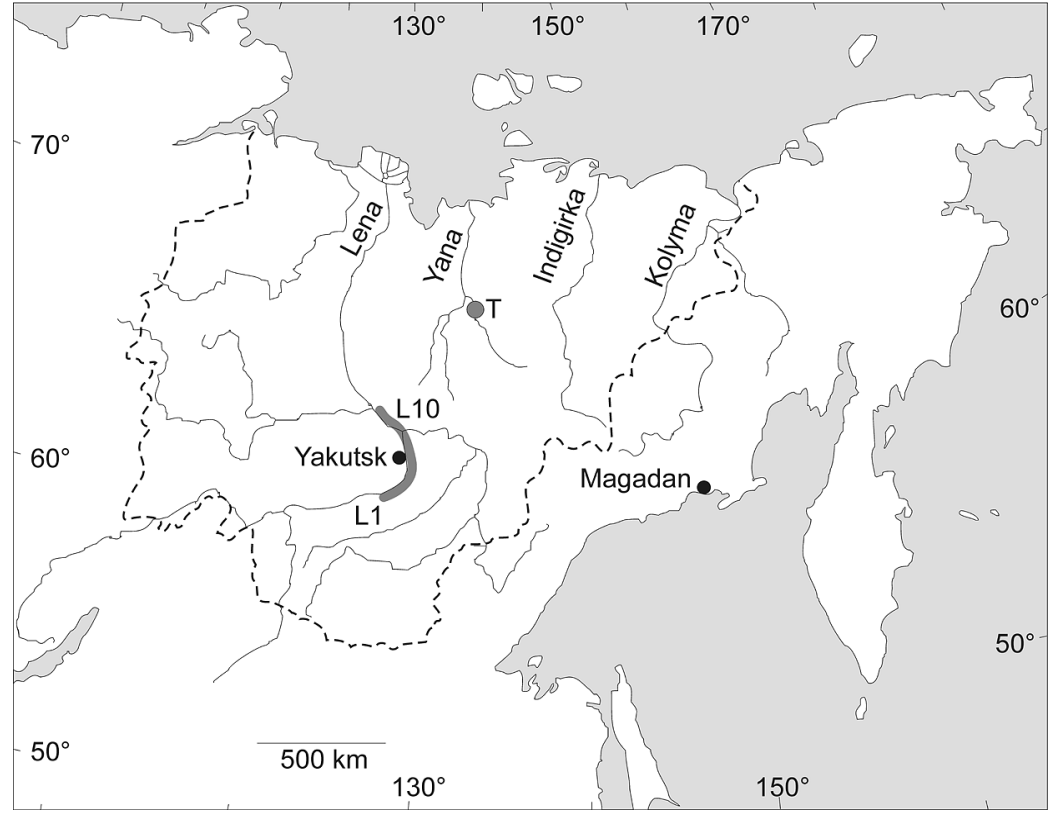

Fig. 1. Collecting sites along the Lena River (shaded area, from L1 to L10) and Tuostach (T) at the Yana River in Yakutia (border indicated by broken line). forestry organized the A. K. Cajander - R. B. Poppius memorial excursion and symposium along the Lena River in summer 2002. The authors SK and NP participated in this excursion. The material collected by SK along the Lena River is presented here with older material collected by NP in the Yana River basin.

\section{Material and methods}

All material was collected in the boreal taiga-forest zone. The author SK collected at ten localities along the Lena River, between $61^{\circ} 06^{\prime}$ and $64^{\circ} 27^{\prime} \mathrm{N}$ (Fig. 1). Collecting methods included hand picking, sweep netting and sieving. Altogether 38 species were found.

Sites (L1-L10) at the Lena River, from the south to the north:

L1: Kangalassy Dist., Lenskie Stolby Nat. Park, slope woodland and river shore, $61^{\circ} 06^{\prime} \mathrm{N}$, $127^{\circ} 22^{\prime} \mathrm{E}, 30$.VI.2002

L2: Yakutsk munip., $5 \mathrm{~km} \mathrm{~S}$ of Tabaga, woodland with steppe patches, $61^{\circ} 47^{\prime} \mathrm{N}, 129^{\circ} 40^{\prime} \mathrm{E}$, 30.VI.2002

L3: Yakutsk, willow vegetation near Lena, $62^{\circ} 10^{\prime} \mathrm{N}, 129^{\circ} 50^{\prime} \mathrm{E}, 6 . \mathrm{VII} .2002$

L4: Megino-Kangalassy Dist., Krasnyi ma- jak, Doiduntsky, alluvial grassland island, $62^{\circ} 20^{\prime} \mathrm{N}, 130^{\circ} 05^{\prime} \mathrm{E}, 6$.VII.2002

L5: Ust'-Aldanskiy Dist., $10 \mathrm{~km} \mathrm{~N}$ of Sotensky, grassland, $62^{\circ} 32^{\prime} \mathrm{N}, \quad 130^{\circ} 01^{\prime} \mathrm{E}$, 1.VII.2002

L6: Namtsky Dist., E bank of Lena, S of Aldan Riv. confluence, swampy forest, $63^{\circ} 18^{\prime} \mathrm{N}$, 129³7’'E, 2.VII.2002

L7: Ust'-Aldanskiy Dist., $\mathrm{N}$ bank of Aldan Riv. at confluence with Lena, woodland, $63^{\circ} 28^{\prime} \mathrm{N}, 129^{\circ} 32^{\prime} \mathrm{E}, 2$.VII. 2002

L8: Kobyay Dist., Ust'-Vilyuy Range, Khoyguolakh Riv., woodland, $64^{\circ} 27^{\prime} \mathrm{N}$, $126^{\circ} 24^{\prime}$ N, 3.VII. 2002

L9: Kobyay Dist., Ust'-Vilyuy Range, Khoyguolakh Riv., stony slope, 200-300 m, $64^{\circ} 27^{\prime} \mathrm{N}, 126^{\circ} 24^{\prime} \mathrm{E}, 3$.VIII.2002

L10: Kobyay Dist., Ust'-Vilyuy Range, Khoyguolakh Riv., litter, $200 \mathrm{~m}, 64^{\circ} 27^{\prime} \mathrm{N}$, $126^{\circ} 24^{\prime} \mathrm{E}, 4$.VII.2002

Material from Verchoyansk region: Yana River basin, Tuostach River (the right tributary of the River Adycha), $67^{\circ} 25^{\prime} \mathrm{N}, 137^{\circ} 06^{\prime} \mathrm{E}$ (Fig. 1), was collected in 1989 by V. V. Sivsev and in 1990 by the author NP. The site included larch forest and burned forest areas. Spiders were collected mainly by pitfall traps. Altogether 50 species of spiders were found at Tuostach. 
The total material included 77 species and is deposited in the Zoological Museum of the University of Turku.

\section{Spiders found}

A question mark after the name of a few species indicates a somewhat unclear identity. These include females or subadult specimens.

\subsection{Species collected along the Lena River, 2002}

Araneidae Aculepeira packardi (Thorell, 1875) - L6 Araniella displicata (Hentz, 1847)? - L7 Larinioides cornutus (Clerck, 1757) - L4, L5 Larinioides patagiatus (Clerck, 1757) - L7

Clubionidae

Clubiona riparia L. Koch, 1866 - L6

Clubiona stagnatilis Kulczynski, 1897-L3. First record in Yakutia and the northernmost locality in Asia. The species was previously known to be distributed up to Lake Baikal only (Marusik et al. 2000).

Dictynidae

Dictyna arundinacea (Linnaeus, 1758) - L7

Dictyna major Menge, 1869? - L6

Emblyna annulipes (Blackwall, 1846) - L3

Gnaphosidae

Drassodes cupreus (Blackwall, 1834) - L1

Gnaphosa nigerrima L. Koch, 1877 - L6

Gnaphosa similis Kulczynski, 1926 - L1

Zelotes fratris Chamberlin, 1920 - L8. First record in Yakutia and the northernmost locality within its range. Earlier it was known up to the $62^{\circ} \mathrm{N}$ latitude (Marusik et al. 2000).

Linyphiidae

Agyneta birulai (Kulczynski, 1908) - L9

Dactylopisthes video (Chamberlin \& Ivie, 1947) - L4

Pelecopsis dorniana Heimer, 1987 - L10
Lycosidae

Alopecosa albostriata (Grube, 1861) - L1

Alopecosa borea (Kulczynski, 1908) - L1, L9

Pardosa jeniseica Eskov \& Marusik, 1995 - L2.

This species was never formally reported from Yakutia, but it was mentioned as Pardosa sp. 1 in Marusik et al. (1993).

Pardosa plumipes (Thorell, 1875) - L4

Pardosa ricta (Odenwall, 1901) - L2

Pardosa tesquorum (Odenwall, 1901) - L1

Philodromidae

Philodromus aureolus (Clerck, 1757) - L3

Philodromus fuscomarginatus (DeGeer, 1778) L1

Philodromus histrio (Latreille, 1819) - L2

Tibellus asiaticus Kulczynski, 1908 - L6

Salticidae

Euophrys proszynskii Logunov, Cutler \& Marusik, 1993 - L9. First record in central Yakutia. The species has recently been reported for the first time from northern Yakutia, where it was found at the Kolyma River mouth (Logunov \& Marusik 2002).

Evarcha proszynskii Marusik \& Logunov, 1998 L8. This is the northernmost locality in the range (Logunov \& Marusik 2002). Earlier this species was known from western parts of Yakutia only (sub E. falcata, Marusik et al. 1993).

Heliophanus camtschadalicus Kulczynski, 1885 - L7

Heliophanus patagiatus Thorell, 1875 - L7

Tetragnathidae

Tetragnatha dearmata Thorell, 1873 - L1, L7

Tetragnatha extensa (Linnaeus, 1758) - L2, L4

Tetragnatha pinicola L. Koch, 1870 - L4

Theridiidae

Enoplognatha serratosignata (L. Koch, 1879) L9

Theridion impressum L. Koch, 1881 - L2, L6

Theridion pictum (Walckenaer, 1802) - L3, L7

Theridion sibiricum Marusik, 1988 - L9

Thomisidae

Misumena vatia (Clerck, 1757) - L7 


\subsection{Species collected from the Tuostach River during 1989-1990}

Araneidae

Aculepeira packardi (Thorell, 1875)

Araniella displicata (Hentz, 1847)

Clubionidae

Clubiona riparia L. Koch, 1866

Dictynidae

Arctella lapponica (Holm, 1945)

Dictyna arundinacea (Linnaeus, 1758) - This is the northernmost locality in eastern Siberia (Marusik et al. 2000).

Gnaphosidae

Drassodes mirus Platnick \& Shadab, 1976-One of the northernmost localities within the range. There are previously only two records of this species north of the Polar Circle: in Chukotka (Marusik et al. 1992) and in Kular, Yakutia $\left(\right.$ at $\left.70.5^{\circ} \mathrm{N}\right)$; see Marusik et al. (2002).

Gnaphosa borea Kulczynski, 1908

Gnaphosa microps Holm, 1939

Gnaphosa nigerrima L. Koch, 1877

Gnaphosa sticta Kulczynski, 1908

Haplodrassus hiemalis (Emerton, 1909)

Micaria aenea Thorell, 1871 - First record in the Yana River basin and the northernmost locality in eastern Siberia. Earlier records of this species lie south of $63^{\circ} \mathrm{N}$ (cf. Marusik et al. 1993, 2000).

Micaria alpina L. Koch, 1872

Micaria lenzi Bösenberg, 1899 - One of the northernmost localities in its range. The species has been found at the Kolyma River mouth (Marusik et al. 2000).

Micaria rossica Thorell, 1875 - First record in the Yana River basin and one of the most northern localities in eastern Siberia (Marusik et al. 2000).

Linyphiidae

Agyneta affinisoides (Tanasevitch, 1984)

Agyneta sp. n.?

Erigone psychrophila Thorell, 1872

Mecynargus tungusicus (Eskov, 1981)

Microlinyphia pusilla (Sundevall, 1830)

Oreoneta alpina (Eskov, 1987) - First record in the Yana River basin. Until recently, this species was known from two localities in Yakutia and two localities in the upper Kolyma (Marusik, pers. comm.).

Savignia nenilini Marusik, 1988 - First record in the Yana river basin.

Silometopoides sphagnicola Eskov \& Marusik, 1992 - First record in the Yana River basin.

Walckenaeria karpinskii (O. P.-Cambridge, 1873) - First record in the Yana River basin.

Wiehlenarius boreus Eskov, 1990 - First record of the genus in Yakutia and the northwesternmost locality for the species. New record coincides with previously known northernmost locality in eastern Chukotka (cf. Marusik et al. 1992). Earlier this species was known to be distributed east of Indigirka River (Kolyma River basin, northern Cisokhotia and Chukotka). It has a west Beringian hypoarctic - montane range (Eskov 1994).

Lycosidae

Alopecosa albostriata (Grube, 1861)

Alopecosa borea (Kulczynski, 1908)

Alopecosa kulczynski Sternbergs, 1979?

Alopecosa sibirica (Kulczynski, 1908)

Pardosa adustella (Roewer, 1951)

Pardosa algens (Kulczynski, 1908)

Pardosa lapponica (Thorell, 1872)

Pardosa lyrata (Odenwall, 1901) - First record in the Yana River basin and the northernmost locality of its range.

Pardosa sodalis Holm, 1970

Pardosa tesquorum (Odenwall, 1901)

Tricca alpigena (Doleschall, 1852)

Philodromidae

Philodromus alascensis Keyserling, 1884

Thanatus albomaculatus Kulczynski, 1908

Thanatus arcticus Thorell, 1872

Thanatus striatus C.L. Koch, 1845 - First record in the Yana River basin and the northernmost locality in Yakutia (Marusik et al. 2000).

Salticidae

Pellenes ignifrons (Grube, 1861) - First record in the Yana River basin and one of the northernmost localities in its range; it is known from the Kolyma River mouth (Logunov \& Marusik 2002). 
Pellenes limbatus Kulczynski, 1895 - First record in the Yana River basin and the northernmost locality in its range. The earlier known records lie south of $65^{\circ} \mathrm{N}$ (Logunov \& Marusik 2002).

Tetragnathidae

Tetragnatha extensa (Linnaeus, 1758)

Theridiidae

Theridion impressum L. Koch, 1881 - This is the northernmost locality in Asia (Marusik et al. 2000).

Thomisidae

Ozyptila arctica Kulczynski, 1908

Xysticus austrosibiricus Logunov \& Marusik, 1998 - First record in the Yana River basin and the northeasternmost locality in its range (Marusik et al. 2000).

Xysticus baltistanus (Caporiacco, 1935) - The northernmost locality in Yakutia (Marusik et al. 1993).

Xysticus britcheri Gertsch, 1934

Xysticus emertoni Keyserling, 1880

Titanoecidae

Titanoeca sibirica L. Koch, 1879 - One of the northernmost localities within its range; present in the Kolyma River mouth (Marusik et al. 2000).

\section{Discussion}

We made several zoogeographically interesting observations. These include four species new to Yakutia: Clubiona stagnatilis, Zelotes fratris and Pardosa jeniseica, all from the Lena River valley, and Wiehlenarius boreus from the Tuostach River. The northernmost localities within their whole range were found for Zelotes fratris, Pardosa lyrata, Evarcha proszynskii and Pellenes limbatus, the northeasternmost and northwesternmost sites for Xysticus austrosibiricus and Wiehlenarius boreus, respectively. The northernmost localities in Asia were recorded for Clubiona stagnatilis and Theridion impressum. The northernmost records in eastern Siberia were found for Dictyna arundinacea and
Micaria aenea, and the northernmost localities in Yakutia for Thanatus striatus and Xysticus baltistanus. Six additional species were new to the Yana River basin: Micaria rossica, Oreoneta alpina, Savignia nenilini, Silometopoides sphagnicola, Walckenaeria karpinskii and Pellenes ignifrons. Two salticids, Euophrys proszynskii and Evarcha proszynskii, were new to Central Yakutia.

Acknowledgements. Many thanks for help and company to N. S. Karpov, to his colleagues from Yakutsk, and to the Finnish participants of the A. K. Cajander-R. B. Poppius memorial field excursion along the Lena River, 2002. SK's participation was supported by the Turku University Foundation and the Societas Entomologica Helsingforsiensis. YM's stay and research in Turku was supported by the Academy of Finland (project \#202579), the Russian Foundation for Basic Research (grants \# 01-04-48989, 04-0448727) and the Far-East Branch of the Russian Academy of Sciences (grant \# 04-3-A-06-042). Veikko Rinne (Turku) kindly compiled the map.

\section{References}

Eskov, K. Y. 1994: Catalogue of the linyphiid spiders of northern Asia (Arachnida, Araneae, Linyphiidae). Pensoft Publ., Sofia-Moscow, 144 pp.

Grube, A.E. 1861-62: Beschreibungen neuer, von den Herren L. v. Schrenk, Maak, C.v. Dittmar u.a. im Amurgebiet und Ostsibirien gesammelter Arachniden. - Bull. Acad. Sci. Imp. St.-Petersbourg 4: 1-29 and 161-180.

Hämet-Ahti, L. 1970: A. K. Cajander's vascular plant collection from the Lena River, Siberia, with its ecological and floristic notes. - Ann. Bot. Fennici 7: 255324.

Koponen, S. \& Marusik, Yu. M. 1992: Spiders (Araneae) from Central Yakutia, Siberia. — Entomol. Fennica 3: 163-166.

Kulczynski, V. 1908: Araneae et Oribatidae expeditionum Rossicarum in insulas Novo-Sibiricas annis 18851886 et 1900-1903 suspectarum. - Mem. Acad. Imp. Sci. St. Peterbourg. Ser. 8, 18(7): 1-97.

Logunov, D. V. \& Marusik, Yu. M. 2002: Catalogue of the jumping spiders of northern Asia (Arachnida, Araneae, Salticidae). — KMK Scientific Press, Moscow, 300 pp.

Marusik, Yu. M. \& Koponen, S. 2002: Diversity of spiders in boreal and arctic zones. - J. Arachnol. 30: 205210.

Marusik, Yu. M., Eskov, K. Yu. \& Kim, J. P. 1992: A check list of spiders (Aranei) of Northeast Asia. - Korean Arachnol. 8: 129-158.

Marusik, Yu.M., Eskov, K. Yu., Koponen, S. \& Vinokurov, N.N. 1993: A check-list of the spiders (Aranei) of 
Yakutia, Siberia. - Arthropoda Selecta 2: 63-79.

Marusik, Yu. M., Logunov, D. V. \& Koponen, S. 2000: Spiders of Tuva, South Siberia. - Inst. for Biol. Problems of North, Magadan, 252 pp.

Marusik, Yu. M., Koponen, S., Vinokurov, N. N. \& Nogovitsyna, S. N. 2002: Spiders (Aranei) from northernmost forest-tundra of northeastern Yakutia $\left(70^{\circ} 35^{\prime} \mathrm{N}, 134^{\circ} 34^{\prime} \mathrm{E}\right)$ with description of three new species. - Arthropoda Selecta 10: 351-370.

Poppius, R. B. 1905: Beiträge zur Kenntnis der Coleopteren-Fauna des Lena-Thales in Ost-Sibirien. I. Haliplidae und Dytiscidae. - Öfvers. Finska Vet.Soc. Förh. 47(16): 1-24.
Poppius, R. B. 1906: Beiträge zur Kenntnis der Coleopteren-Fauna des Lena-Thales in Ost-Sibirien. II. Cicindelidae und Carabidae. — Öfvers. Finska Vet.Soc. Förh. 48(3): 1-65.

Poppius, R. B. 1907: Beiträge zur Kenntnis der Coleopteren-Fauna des Lena-Thales in Ost-Sibirien. III. Cyrinidae, Hydrophilidae, Georyssidae, Parnidae, Heteroceridae, Lathridiidae und Scarabaeidae. Öfvers. Finska Vet.-Soc. Förh. 49(2): 1-17.

Poppius, R. B. 1909: Beiträge zur Kenntnis der Coleopteren-Fauna des Lena-Thales in Ost-Sibirien. IV. Staphylinidae. — Öfvers. Finska Vet.-Soc. Förh. 51(4): 1-48. 